IOLANDA MǍNESCU

University of Craiova, Romania

\title{
CONTEMPORARY INTERPRETATIONS OF ANCIENT DRAMA AT THE NATIONAL THEATRE OF CRAIOVA, ROMANIA
}

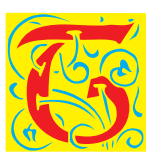

he National Theatre of Craiova is one of the oldest theatres in Romania. It was founded in 1850 but, before that date, some Western companies from France and Germany had visited the town and presented their productions in Craiova, while the local intellectuals would prepare and play short dramas when they organized their meetings, for instance "in winter, especially during the carnival." ${ }^{1}$

We could say that the interest in staging ancient dramas is somehow linked to the moments in history when people, confused by some disturbing events, such as wars or change of political regimes, or even at the turn of centuries or millennia, feel that they should go back to the origins and find there the power to go on. The first ancient tragedy staged in Romania was "Hecuba" by Euripides - it was presented by the students of a famous high school in Bucharest, in 1819. The sociopolitical conditions did not allow a new staging soon after that, and, thus, only at the end of the 19th century the ancient theatre is taken into consideration again. Meanwhile, more translations of the ancient Greek plays had been made. The playwright who was preferred during that time was Sophocles: for instance, "Oedipus the King" was kept in the repertory of the National Theatre of Bucharest from 1890 to 1924. A new significance, with profound contemporary references, was found in the text - the underlining of the human dignity and the passion for knowing the truth.

During the first half of the 20th century, more and more ancient plays were staged in the Romanian theatre. In 1911, and 1912, "Iphighenia in Aulis" was

1 A. Firescu and C. Gheorghiu, History of the National Theatre in Craiova 1850-2000, Craiova, Romania: Aius, 2000, 18. 
presented in the open air, in different cities in Romania. At that time, some Romanian actors began to gain international recognition: Agatha Barsescu for example played in ancient tragedies in Austrian, German and American theatres.

After the Second World War new modalities of staging the ancient plays were found, in order to express the new experience of the war. The profound changes of the society led to finding new texts to be performed: Sophocles's "Antigone" was staged for several years, and Euripides's "Hecuba" was of interest again.

The National Theatre of Craiova staged an ancient play, for the first time, in the season 1943-1944: it was Sophocles's "Oedipus the King". Nevertheless, an ancient drama was staged again only in the 1963-1964 season. Euripides's "The Trojan Women" was meant to remind people that war generates suffering, ruins, destruction, desolation and humiliation, and to warn about the dark perspectives and consequences of the future after the war.

The interest for the ancient drama continued in new ways in the Romanian theatre: the TV shows began to be of great interest for the audiences during the 60s. New performances were either created or adapted for the television. Among the first plays presented on television, we can mention "Medea", "The Trojan Women" or "Alcestis". Also, different theatre festivals began to be organized in the 70s. The first festival of ancient theatre in Romania was organized by the Dramatic Theatre in Constanta, at the Black Sea, in 1978, and the performances took place in different historic places, even around some ancient ruins such as at Histria or Callatis, on the shores of the Pontus Euxinus - the ancient name of the Black Sea. The internationally renowned director Silviu Purcarete started to stage his performances of ancient plays on the occasion of this festival. In 1978 he presented his performance of "The Atreides' Legends" at Histria having in mind the link between cultures, between the Golden Age of the ancient Greece, the Byzantine world, and some ancient Romanian folkloric concepts expressed in poems, dances, and songs such as: "Caloian" (a rain ritual), "Ciuleandra" (a circle dance), and "Miorita" (a ballad). He meant to bring to life the image of a world of myths and dramatic poetry, a world that was "more than old, and more than archaic - a primordial world". ${ }^{2}$ Silviu Purcarete continued to participate in the Festival of Ancient Drama, at the second edition, in 1981, with his performance of "Hecuba", a play that had marked the beginning of presenting performances in the Romanian language, in the early 19th century.

2 S. Purcarete, The Atreides' Legends Playbill, Dramatic Theatre, Constanta, Romania, $1978,2$. 
After December 1989, the Romanian theatre life changed dramatically, the same as the whole Romanian society, and the same as the whole European society. A decisive moment in the history of the National Theatre of Craiova was that when the director Silviu Purcarete started his collaboration with the Craiovan theatre. He staged there several performances and - after he had become famous worldwide with his performances of "Ubu Rex with Scenes from Macbeth" after Alfred Jarry and William Shakespeare, and "Titus Andronicus" by William Shakespeare, which were presented at the best-known theatre festivals such as the festivals in Edinburgh and in Avignon - he started his series of performances of ancient drama staging his performance of "Phaedra" in 1994.

In creating a new performance, Silviu Purcarete has always started his work from an exhaustive informational material, from a detailed research of all sources, and from the study of different translations (not only into Romanian). His theatrical language includes text, image, light and sound in a perfect balance. His performance of "Phaedra" combined Euripides's Hippolytus and Seneca'a Phaedra in his attempt to find the most appealing words to the contemporary society. The set was minimal, only formed of a moving platform that symbolized a bed, and the stools that were permanently carried by the members of the Chorus - the most important character that included a number of eighteen female performers. They represented the well-known Chorus in the ancient drama, and, at times, the character of the Nurse that was mainly played by four actresses. The multiplication of a character is one of the motifs in Silviu Purcarete's works. The huge dark empty stage, dominated by the light of the Moon suggesting the merciless goddess Artemis, the use of only black and white colours, the strange sounds as generated from another world, all these created a mesmerizing atmosphere that the audiences could hardly forget. The next production of an ancient play that he staged at the Craiova National Theatre was The Danaides, a huge production, with more than one hundred performers - it was the collaboration between the National Theatre and some very important international theatre festivals in Avignon, Vienna and Amsterdam. As long as much of the text of this play was lost, Silviu Purcarete not only used the surviving fragments of the tetralogy that included The Suppliants, The Egyptians and The Danaids, but he also introduced commentaries on tragedy by some of the most famous philosophers, critics and playwrights: Aristotle, Corneille, Stendhal, Scaliger, Schopenhauer and Nietzsche.

Silviu Purcarete created several performances at the Craiova National Theatre (mainly ancient drama and Shakespeare) and his latest production of an 
ancient play staged there was "Oresteia", Aeschylus's only completely extant trilogy. It is a play that the director had staged in France, before staging it in Romania. Therefore, the work on the text was all the more complex, as the director had studied several French and Romanian translations, in order to refine the language of the performance, for it to become as coherent to the contemporary audiences as possible.

The interest of the National Theatre for the ancient drama has continued, and another director who staged ancient Greek plays in Craiova was Yiannis Paraskevopoulos who started his Craiovan career with a wonderfully fresh view on a masterpiece of the world playwriting: "Romeo and Juliet" by William Shakespeare. The success of this performance led to a new presence in Craiova of the Greek director whose second performance staged there was "Medea" - a mixture of modern means and traditional Greek aspects that deeply impressed the audiences. The actors were dressed in contemporary costumes but they used traditional Greek gestures and behaviors. Besides the torments of a deceived woman, Medea also suffers the humiliation of the migrants. Therefore, the performance presents one of the most imperative contemporary problems, which was as actual in the ancient times, as it is nowadays. The performance was very successful both in Romania and in Greece where it was acclaimed by the audiences who saw it at the Festival of South-Eastern Europe - Aspects of the Ancient Drama in Thessaloniki and at the International Festival of Ancient Greek Drama in Cyprus. The next performance that Yiannis Paraskevopoulos staged at the National Theatre of Craiova was an ancient Greek comedy: "Lysistrata" by Aristophanes. The theme is again extremely actual, as the play is an anti-war comedy and it approaches the sexual relations in a male-dominant society.

The ancient Greek literature was also present in the repertory of the $\mathrm{Na}$ tional Theatre through the production of "The Odyssey", staged by the British director Tim Carroll who proposed a very innovative approach of Homer's epic poem - each performance was a new retelling of the stories included in the books of "The Odyssey". The actors used improvisation, songs, pantomime, as well as the audiences' stories, while the props were hoops and sticks. All the actors knew all the roles, and they would change the character they performed, randomly, representation to representation. In an epoch of globalization, the attempts of finding a complex language, as accessible as possible to a diversity of peoples and cultures, represents one of the main roles of theatre today. 
We will conclude with one of the director Silviu Purcarete's opinions about the ancient drama that can be a permanent source of inspiration: "It is fascinating. I never feel I am bringing back to life something old; I do not have the feeling that I am dusting something in order to reveal its brightness. On the contrary, this brightness is blinding me. The force of these texts does not need to be discovered because their modernity is aggressive. Whenever I read them, I am very touched, very moved."3

\section{References}

Firescu, A. and Gheorghiu, C., History of the National Theatre in Craiova 1850-2000, Craiova, Romania: Aius, 2000, 18.

Purcarete, S., The Atreides' Legends Playbill, Dramatic Theatre, Constanta, Romania, 1978, 2. Wallace, N., "An Interview with Silviu Purcarete," Oresteia Playbill, Lincoln Center Festival, NYC, USA, 1997, 24C.

3 N. Wallace, "An Interview with Silviu Purcarete," Oresteia Playbill, Lincoln Center Festival, NYC, USA, 1997, 24C. 